\title{
Robert Herrick and the five (or six) senses
}

\author{
Natalie K. Eschenbaum
}

When you descend to the lower level of the Art Museum of New South Wales, you are greeted with an intense, pungent, but welcoming aroma. Cinnamon, cardamom and cloves - the same spices that lured English Renaissance traders to India - draw you into a room that houses Ernesto Neto's installation, Fust Like Drops in Time, Nothing. ${ }^{1}$ Dozens of massive semi-transparent tubes of stocking-like fabric hang from the ceiling, weighted down by hundreds of pounds of ground spices. As Neto's title prompts, the spices look and act 'like drops' of liquid; their access to the sense of smell is as important as their material nature. The museum's Director Curatorial, Anthony Bond, explains how the body and its senses are central to Neto's work: '[The] spice[s] swell the fabric in voluptuous almost bodily forms that fill the gallery space and our olfactory organs with [their] aromatic intensity.' To engage with this art is to become part of it, because your 'body ingests the work and is simultaneously ingested by it'. Neto uses the sense of smell to question the boundaries between people and things: 'Scent entails the physical invasion of the body by its particles unlike vision that always exists as a translation conveyed to the eye by light from a distance. ${ }^{2}$ He forces viewers to smell his art, inviting the possibility that sensation is always invasive.

Although Neto's installation, as well as Bond's description of it, stem from a modern understanding (or imagining) of sensation, Robert Herrick's early modern English verse similarly explores the surfaces of bodies, their sensing orifices and the liquefying experiences of sensation. Herrick, however, does imagine all five senses to enable 'physical invasion of the body'. In 'The Argument of his Book', he provides a partial table of contents for Hesperides (1648), his collection of over 1400 poems. The things emphasized at the midpoint of the verse catalogue are liquids and sensual objects: 'I sing of Demes, of Raines, and piece by piece | Of Balme, of Oyle, of Spice, and Amber-Greece' (1l. 7-8). ${ }^{3}$ Throughout Hesperides, Herrick sings of things that enliven the senses, and he describes sensation as a process of absorption or consumption. For instance, like Neto's spices, the body absorbs the ambergris-based perfume through the sense of smell. In this chapter, I argue that Herrick's poetics reveal that all 
objects act like fluids when they are seen, tasted, touched, heard or smelled - or, rather, when they are textualized or poeticized as sensible things.

Critical interest in the senses in early modern literature has increased steadily in recent years, as evidenced by this collection. Sense experiences are historically specific, and, Susan Stewart explains, the 'forms of their articulation and expression in works of art give us an historical account of how such experiences [...] are transformed'. ${ }^{4}$ In early modern England, most writers agreed with Aristotle's general assertion that knowledge happens via the senses: 'if one perceived nothing one would learn nothing, ${ }^{5}$ Sensation allowed early moderns to, quite literally, make sense of their realities.

By the time Herrick published Hesperides there was a long tradition of poetic sensoria, or verses specifically devoted to the five senses. Examples include Richard de Fournival's Bestiare d'amour (c. 1240), Edmund Spenser's The Faerie Queen 2.11 (1590), George Chapman's Ovid's Banquet of Sence (1595), Thomas Tomkis's play Lingua (1607) and Michael Drayton's Idea XXIX, 'To the Senses' (1616). The narrator of Drayton's sonnet, for example, calls upon each sense in his attempt to thwart Love's attack on his heart:

But he with beauty first corrupted sight,

My hearing bribed with her tongue's harmony,

My taste by her sweet lips drawn with delight,

My smelling won with her breath's spicery,

But when my touching came to play his part

The king of senses, greater than the rest,

He yields Love up the keys unto my heart[.] $]^{6}$

In The Five Senses: Studies in a Literary Tradition, Louise Vinge offers an impressive survey of these sensual verse catalogues. She mentions Cowley's 'The Soul' (1647) and Cleveland's 'To the State of Love, Or, the Senses' Festival' (1651) to demonstrate how the five senses topos persisted in mid-seventeenth-century love poetry. ${ }^{7}$ Herrick, publishing at this time, would have been aware of the tradition. But Hesperides is not part of Vinge's survey because Herrick does not have a single poem, or a defined series of poems, that catalogues all five senses. 'Of Love. A Sonet' is the closest he comes to this tradition:

How Love came in, I do not know,

Whether by th'eye, or eare, or no:

Or whether with the soule it came

(At first) infused with the same:

Whether in part 'tis here or there,

Or, like the soule, whole every where:

This troubles me: but I as well

As any other, this can tell;

That when from hence she does depart,

The out-let then is from the heart. 
Herrick nods to the sensorium tradition, but does something different here. His narrator admits that the science of sensation, as it relates to love, confuses him. He knows he is in love because his heart aches when his beloved departs. When in love, the usual ways in which we gain knowledge and confirm reality - our bodily senses - are not helpful. When in love, our bodies are infused with the feeling and, perhaps, with the soul of our beloved.

Herrick's choice of the word infuse (from the Latin, infundere, meaning 'to pour in') predicts the way in which he describes the liquefying function of the five senses throughout Hesperides. ${ }^{8}$ Even though his collection does not include a traditional poetic sensorium, and even though 'Of Love. A Sonet' seems to dismiss the senses, Herrick writes dozens of poems about seeing, hearing, smelling, tasting and touching things and people. In Hesperides, to sensually engage with things or people is usually to infuse with them, to melt into them, to liquefy.

Herrick's poems about seeing his beloved Julia are probably the best examples of the effects of intrusive, liquid sensation. Take, for instance, the oft-anthologized 'Upon Julia's Clothes':

When as in silks my Fulia goes,

Then, then (me thinks) how sweetly flowes

That liquefaction of her clothes

Next, when I cast mine eyes and see

That brave Vibration each way free;

O how that glittering taketh me!

The description of Julia's clothing reflects the experience of visual sensation. The effect of the vision mirrors the vision itself. In the first stanza, the narrator describes Julia's silk clothing flowing like a river. The parenthetical 'me thinks' implies that he does not yet see the clothing, but is simply imagining the undulating liquid cloth. The second stanza then opens with him seeing the clothes by 'cast[ing]' his eyes, like a fisherman throwing his line into a river. The narrator does not just see the silken river, but he throws his eyeballs into it. He then realizes that he is at the wrong end of the fishing pole (as is often the case in these sorts of fishing allusions). He cannot capture the glittering, liquid clothing, but rather is taken, or captured, by it. The experience of seeing the river is the experience of becoming a river. To see is to liquefy and to become one with that which you see. Seeing is infusion.

Herrick describes a similar experience of visual sensation in 'Julia's Petticoat'. Here, the narrator 'behold[s]' an 'Azure Robe' (1. 1). The wonderfully tactile verb, 'behold', suggests a physical joining of the seer with the thing seen. The petticoat comes to life in the narrator's vision of it; it goes 'wandring' and 'two'd pant, and sigh, and heave' (1l. 3, 5). But seeing the petticoat's animated movements causes the narrator to liquefy again: 
Sometimes away 'two'd wildly fling;

Then to thy thighs so closely cling,

That some conceit did melt me downe,

As Lovers fall into a swoone:

And all confus'd, I there did lie

Drown'd in Delights; but co'd not die.

That Leading Cloud, I follow'd still,

Hoping t'ave seene of it my fill;

But ah! I co'd not: sho'd it move

To Life Eternal, I co'd love.

(11. 13-22)

The blue petticoat flows when Julia moves, periodically 'cling[ing]' to her thighs and revealing her body's outline. This visual image conjures in the narrator's mind a 'conceit', or a 'fanciful notion', that makes him melt and then drown.' One can only guess what sort of 'fanciful notion' he conjures, but the poem cares less about what is imagined than it does about the physical effects of seeing. He is not content simply to lie 'Drown'd in [the] Delights' of what he has imagined, but he needs to keep drinking in the vision of the petticoat. He keeps following that 'Cloud' - a billowing, moving body of liquid - and says he hopes ' $t$ 'ave seene of it my fill'. To see is to ingest, as you would drink or food. Sight is sustenance, even if it, like love, is insatiable.

In these poems about Julia's clothing, seeing is a liquid process that conjoins the viewer with that which is seen. Herrick's poems about hearing similarly melt together the listener with that which is heard. In another Julia poem, 'Upon Julia's Voice', the narrator describes her singing:

So smooth, so sweet, so silv'ry is thy voice,

As, could they hear, the Damn'd would make no noise,

But listen to thee, (walking in thy chamber)

Melting melodious words, to Lutes of Amber.

Julia's voice, accompanied by lutes, is so beautiful that even those suffering in Hell would be silenced if they could hear her. They would simply stand, mesmerized, and drink in the sound of her voice (like the narrator who is sustained by drinking in the vision of her moving petticoat). Herrick's own language depicts the beauty of Julia's singing through alliterative onomatopoeia. The first and fourth lines melt their own 'melodious words'; like her voice, his poetry is '[s]o smooth, so sweet, so silv'ry'. Herrick's poetic voice mirrors, or melts into, Julia's. Her voice is his poetry, and his poetry is her voice.

In 'Againe', the poem immediately following 'Upon Julia's Voice', the narrator hears her voice and claims to lose his own:

When I thy singing next shall heare,

Ile wish I might turne all to eare, 
To drink in Notes, and Numbers; such

As blessed soules cann't heare too much:

Then melted down, there let me lye

Entranc'd, and lost confusedly:

And by thy Musique strucken mute,

Die, and be turn'd into a Lute.

Here, the ear is given the mouth-like ability to drink in liquid music. Herrick's narrator asks to 'turne all to eare', so that his entire being can consume (and be consumed by) Julia's voice. He asks to be like 'blessed soules' who are not limited by physical bodies and their senses. Souls, as we saw in 'Of Love. A Sonet', are like liquids that can be poured into and out of bodies. The narrator wants to immerse himself in listening so completely that he loses himself and becomes the sound that entrances him. Indeed, he refers to himself as 'I' - a subject - three times in the first two lines. As soon as he wishes to be turned into an ear - an object - the first person subject disappears. The listener (or, rather, the 'ear') melts down with complete consumption of the liquid music, where he (or, rather, it) asks passively to be 'let' to 'lye'. As a melted, entranced, confused object (confused, because he is no longer an 'I'), the listener relinquishes all control to the music.

In both of these poems, sounds have metamorphic power. They can change solids to liquids and people to things. Herrick gives scents this same power. As Neto demonstrates with his spiced art installation, smelling is a more intrusive sense. We can smell from afar, but scents (like tastes, but less voluntary) are drawn into the body. Perhaps predictably, Hesperides also includes a poem about smelling Julia. In 'Upon Julia's sweat' Herrick's narrator asks if we would like 'oyle of Blossomes', or a floral perfume, and informs us that we can 'Take it from my Julia's sweat' (11. 1-2). Her sweat, he says, smells like lilies and lavender and should be bottled. Similarly, when she breathes we can capture 'rich spices' that 'flow' from her mouth (1. 6). Like visions and sounds, scents act like liquids when they 'flow' from a person's body. 'To Dewes. A Song' also describes scents, but this time to capture the feeling of being in love. It begins with the narrator asking liquid dew to 'consume' the fire of Love that burns within him, '[a]lthough the Pile be all perfume' (11. 3-4). The funeral pile might smell sweet, like Julia's breath, but it is incinerating him nonetheless. He continues:

Alas! the heat and death's the same;

Whether by choice, or common flame:

To be in Oyle of Roses drown'd,

Or water; where's the comfort found?

Both bring one death; and I die here [...]

(11. 5-9) 
To drown is to die, whether the vehicle is plain water or scented rose oil. What this means, though, is that being in love feels like burning in spice or drowning in floral perfume. Being in love feels like being overwhelmed by, and losing yourself in, your beloved's scents. Smelling, like seeing and hearing, is a liquid process that directly affects the sensor.

In Hesperides, scents change things as well as people. One of Herrick's epigrams, 'The Custard', describes a piping hot dessert that is delivered to a dinner table. A man named Furze, 'three or foure times with his cheeks did blow | Upon the Custard, and thus cooled so' (11. 3-4). Furze cools the custard, but the narrator informs us that now 'none co'd eate it, 'cause it stunk so much' (1. 6). Unlike Julia, who would have spiced the custard with her scented breath, Furze's disgusting breath taints the custard, making it inedible. Lungs, another foul-breathed individual, does not even need to blow on food to corrupt it; he just sits at the table and 'his breath do's Fly-blow all the meate' ('Upon Lungs. Epigram', 1. 2). Lungs's breath is so foul that meat begins to decompose, to crawl with maggots, simply when he is in its presence. Scents are powerful. Whether you are custard, meat or a person, smells get under your skin and change your composition, for better or for worse.

The epigrams about tainted foodstuffs are as much about the sense of taste as they are about smell. The noxious smells emanating from the custard and meat are warnings that the food should not be tasted. Because of its connection with eating and drinking, taste is the sense that most obviously draws substances into, and changes, the body. In 'Upon Jack and Jill' Herrick describes the physical effects of taste while playfully poking fun at his own art:

When Fill complaines to fack for want of meate;

Fack kisses Fill, and bids her freely eate:

Fill sayes, of what? sayes Fack, on that sweet kisse,

Which full of Nectar and Ambrosia is,

The food of Poets; so I thought sayes Fill,

That makes them looke so lanke, so Ghost-like still.

Let Poets feed on aire, or what they will;

Let me feed full, till that I fart, sayes Fill.

Jill dismisses the substitution of tasty kisses for solid food because, she says, sweet tastes are not enough. She wants to be full enough to fart, which will only happen if she consumes substantial food or drink. But even though the poem dismisses figurative language (kisses taste like nectar and ambrosia), much like that which we have seen Herrick himself use (sweat smells like perfume), Jill reveals how it still has tangible effects. When poets feed on metaphors, or nothing, or air, their bodies become 'lanke, so Ghost-like'. The effects of not eating solid food, of solely tasting ambrosial kisses, are equally real and substantially change the composition of bodies. Also, Jill responds to Jack's sweet metaphor by creating her own figurative image (poets feed on air). Poetry begets more poetry. 
'Upon Loach' provides a very different kind of 'sweet' taste:

Seeal'd up with Night-gum, Loach each morning lyes,

Till his Wife licking, so unglews his eyes.

No question then, but such a lick is sweet,

When a warm tongue do's with such Ambers meet.

Taste is another fluid sense. It is connected to liquid saliva, which can taste like nectar (Jack's kisses) or dissolve eye-gum (Mrs Loach's licks). But 'Upon Loach' reveals that taste is fluid in another manner; tastes change based on who does the tasting. I might find Loach's coagulated eye drainage to be salty and disgusting, but his wife makes the action and taste 'sweet' because she loves him. As William Miller explains, rules of disgust 'mark the boundaries of self; the relaxing of them marks privilege, intimacy, duty, [...] caring. ${ }^{10}$ Herrick confirms the fluid nature of taste in 'Upon Teares': 'Teares, though th'are here below the sinners brine, | Above they are the Angels spiced wine'. Depending on who does the tasting, brine can be wine, and wine can be brine. We saw that smells change the composition of people and things; tastes work in similar, fluid ways, and reveal that experiences of sensation differ from person to person.

To taste is also to touch, but, outside of tasting, this fifth bodily sense is the least explored in Hesperides. Indeed, Herrick frequently has been charged with fetishism because his narrator desires from a distance. Lillian Schanfield demonstrates this critical tendency in "Tickled with Desire": A View of Eroticism in Herrick's Poetry' when she says Herrick is a 'silent, prowling visitor from that all-too-Freudian world of repressed fantasies and sublimated sexual energies'. ${ }^{11}$ According to Schanfield, Herrick 'mentally disrobes', 'praises' and 'sniffs' his mistresses, but undressing, kissing or otherwise touching them exists only in the space of fantasy. ${ }^{12}$ Hesperides certainly includes a number of poems about imagined contact with women (an illustrative example is 'The Vine', where the narrator dreams his vine-like penis is exploring his mistress's body), but Herrick's narrator does reach out from time to time. For instance, in 'Upon Julia's Breasts', he asks Julia to display her breasts, so that he can first 'Behold' them (1. 2), and then touch (and taste) them: 'Betweene whose glories, there my lips Ile lay, | Ravisht, in that faire Via Lactea' (1l. 3-4). He compares her breasts to the Milky Way, probably to describe both their pale colour and their physical function. By laying his lips on her breasts, he could simply be nuzzling them, but he also could be kissing and perhaps even suckling from them. Considering he places his lips 'betweene' her breasts, this final reading is unlikely. But even if the poem is not a description of lactophilia, Herrick describes touch as another fluid sense. Touching Julia's breasts is like drinking them in, and this sensation ravishes the narrator in the same way that the vision of her silken skirts and the sound of her singing did.

Another poem about Julia confirms this fluid reading of touch. 'Upon Julia's 
Washing Her Self in the River' begins with vision and ends (perhaps?) with touch:

How fierce was I, when I did see

My fulia wash her self in thee!

So Lillies thorough Christall look:

So purest pebbles in the brooke:

As in the River Fulia did,

Halfe with a Lawne of water hid, Into thy streames my self I threw, And strugling there, I kist thee too;

And more had done (it is confest)

Had not thy waves forbad the rest.

When Herrick's narrator gazes at Julia's naked body he grows jealous of the river that caresses and partially conceals her. Instead of trying to touch her, he throws himself into the river. As he thrashes around, he finds himself kissing the river and admitting that 'more had done' if the water had been calmer. He attempts to make love to the river, because touching the river is touching Julia. The river has absorbed her being; by touching the river, he can touch her. ${ }^{13}$

This tour through Herrick's sensorium complicates our understanding of early modern sensation. First, in Herrick's imagination, sensation is a liquid process that infuses the sensor with what, or who, is sensed. When we sense, we do not simply drink the world in through five portals; rather, to sense is to melt, to conjoin with what is sensed, and to change the composition of our selves as well as the things and people we encounter. Second, sensation is frequently, and perhaps always, related to love or lust. The poems that describe one or more of the senses do so because they also describe desire. And, third, Herrick suggests that poetry itself functions like the people and things that are sensed. This is, in part, because poetry is music and has the same liquid and transformative powers as anything else that is sensed. When seen or heard, poems get under our skin. Those that focus on the five senses may even have the power to change how we understand and experience sensation at large.

To begin to make sense of Herrick's sensorium of liquids, lusts and lyrics, we must turn to the philosophical and medical texts that defined sensation for him and his contemporaries. Louise Vinge explains:

what was said in literary works about the sense-organs and their functions depended on natural science and anatomy. Several ideas and images originally came from treatises by philosophers - Aristotle of course being the most influential - and physicians, and by repeating their phrases in compilations, medieval scholars handed them on. ${ }^{14}$

By the seventeenth century, most descriptions of the five senses acknowledge, if they do not parrot, Aristotle's philosophy from De Anima (On the Soul). Aristotle is frequently credited with categorizing and defining the senses as five, 
although Vinge reminds us that the 'division [...] had been accepted long before and was even subjected to criticism. But naturally it later gained a position that was almost unshakable simply because it was authorized by Aristotle. ${ }^{15}$ Even the order in which most writers describe the senses, from high to low (sight, hearing, smell, taste, touch), is the one Aristotle provides in his seminal text (II.6-11; pp. 172-87).

At least two of Aristotle's observations are worth considering alongside Herrick's verse. In De Anima, Aristotle asserts that sense perception is the faculty of receiving the forms of objects independently of the matter of which they are composed. He draws an analogy to explain how the 'sense is the recipient of the perceived forms without their matter, as the wax takes the sign from the ring without the iron and gold - it takes, that is, the gold or bronze sign, but not as gold or bronze' (II.12; p. 187). Our senses are like soft wax, he says, and when we come into contact with something, the sensed object will only leave a matter-less imprint on the sense. If it is a gold ring we see, for instance, only an image of that ring will impress itself on to our sight; no gold will actually travel into our eyeballs. So far, it seems Herrick might disagree. When his characters sense, their bodies are physically affected, and people have the ability to infuse with that which they sense. Later on, however, Aristotle qualifies his statement by limiting it to the three highest senses: 'Neither light nor darkness nor sound nor smell has any effect on bodies. [...] But the tangible objects and the flavours do affect them directly' (II.12; p. 188). According to Aristotle, when we taste or touch things their matter does have a direct effect on our bodies. Herrick imagines all five senses to function like taste and touch, the senses that have the ability to draw matter into the body.

Although Aristotle says sight, hearing and smell do not transfer matter, he does tell us that all bodily senses require a medium for perception to occur. The sense organs never act directly. For instance, in the case of sight: 'If someone puts what has colour on the sight-organ itself, he will not see it. In fact, colour moves the transparent, the air, say, and by this if continuous the sense-organ is moved' (II.7; p. 175). He continues:

the same account can be given in the case of sound and smell. For none of them produces the sensation by touching the sense-organ, rather it is the medium that is moved by smell and sound and each of the sense-organs by this. And when anyone puts the sound or smell source on the organ itself, this produces no sensation. It is the same situation, only not apparently so, with touch and taste. (II.7; p. 175)

Aristotle argues that for sensation to occur there needs to be distance between the sense organ and what is sensed. This distance is not empty space, but it is filled with a substance (air, water, spit) that carries the sensual impression. So, even if matter is not transferred via the medium, the medium itself has to touch the origin and the destination. You could argue, then, that the medium conjoins 
the sensor with what is sensed. This is what Herrick might be exploring in a poem like 'Upon Julia's Washing Her Self in the River', where the narrator literally embraces the medium (water) that physically separates him from his beloved.

Aristotle's philosophy probably influenced Herrick, but the depictions of sensation in Hesperides align more intriguingly with the Epicurean ideas of Lucretius in De rerum natura (On the Nature of the Universe). In Sensible Flesh, Elizabeth Harvey describes Lucretius as an early 'materialist' who believed 'touch forms the basis for the other four senses'. ${ }^{16}$ Lucretius claims there is a material connection between people and that which they sense. Sights, sounds, smells, tastes and textures do not just travel through media; small particles actually break off what is sensed and travel into the person who senses. All sensed objects touch the body of the sensor. Misty Anderson articulates this philosophy well: "Sensory perceptions that "penetrate" the body though [sic] touch are Lucretius's paradigm for sensation and hence knowledge. ${ }^{17}$ For example, Lucretius describes how theatre awnings physically touch people and things with their colour particles. The awnings '[spray] particles from their surfaces this way and that', and these particles instantaneously settle on the actors and their props. ${ }^{18}$ The people and things 'are made to glow and flow with the colours of the canopy' that flaps above them (Iv.78-79; p. 97). In another example, when stars twinkle above a calm lake, 'immediately the sparkling constellations of the firmament in all their unclouded splendour twinkle back reproduced in the water' (Iv.212-14; p. 100). The stars in the water are made up of 'flimsy tissues' that are thrown off from the actual stars (Iv.158; p. 99). If Herrick's narrator were to dive into this water, he would conjoin with actual star particles. Perhaps Julia's reflection in the river is not just a reflection; it is a tissue made up of pieces of her. When he dives into the reflective water, the narrator actually conjoins with these pieces and so with her.

Everything in the world is matter, according to Epicurean philosophy (and unlike Aristotelian philosophy), and sensation only happens when bodies collide with other bodies, no matter the sense. As Lucretius notes, hearing works like seeing:

all forms of sound and vocal utterance become audible when they have slipped into the ear and provoked sensation by the impact of their own bodies. The fact that voices and other sounds can impinge on the senses is itself a proof of their corporeal nature. (IV.525-29; p. 108)

This material understanding of sensation demonstrates why, when it comes to taste, some corporeal collisions are pleasant, while others are unpleasant: 'When something sweet to one is bitter to another, it must be because its smoothest particles caressingly penetrate the palate of the former, whereas the latter's gullet is evidently invaded by particles that are rough and jagged' (Iv.658-61; p. 112). This philosophy helps to explain, for instance, why Lungs's stinky breath 
spoils meat. Diseased, smelly particles throw themselves out of Lungs's mouth and infuse themselves with the meat.

It is tempting to argue that Herrick read Lucretius and these philosophies made their way into Hesperides. Here is what we do know: De rerum natura was rediscovered and published in Italy in the early $1500 \mathrm{~s} ;{ }^{19}$ it was probably translated into English by the memoirist Lucy Hutchinson in the 1640 s or $1650 \mathrm{~s} ;{ }^{20}$ it gained popularity in the late seventeenth century and a handful of editions were published in both Latin and English (most notably, John Evelyn and John Dryden translated excerpts); ${ }^{21}$ and biographies often describe Herrick as an Epicurean. ${ }^{22}$ It is possible that Herrick was ahead of his time, and that he embraced this philosophy before his compeers. But it is equally possible that Herrick was influenced by other theories of sensation that saw the process as physical and intrusive. In The Key of Green, Bruce Smith explains how the seventeenth century experienced a dramatic 'shift in thought about thought'. Smith describes a pre-Cartesian understanding of sensation:

According to the model of the mind [...] inherited from Aristotle, Galen, Avicenna, Averroës, St. Augustine, and Aristotle's scholastic disciples, all knowledge begins with sense experience. [...] The route from the senses to the intellect was not, however, the direct electrical connection between sense organs and brain mapped by modern physiology. [...] Rather, a circuit through the heart via the vaporous fluid spiritus was imagined to act as the body's internal communication system. As a result, sensation was a whole-body experience.

To sense something was to invite the 'vaporous fluid spiritus' to course through, and to necessarily affect, your entire body. The effect would be felt with the 'excitation [...] of the body's four humors according to whether the heart dilated in desire or contracted in avoidance'. And then you would experience 'this rush of humors throughout the body as passion of one sort or another'. ${ }^{23}$ In this way, seventeenth-century sensation is akin to liquefaction, as Herrick suggests in his verse.

Herrick may or may not have read Lucretius, but he certainly was aware of Galenic theories of the bodily humours and the resulting passions. Numerous poems in Hesperides mention the humours, and Smith notes that 'more than thirty books with "passions" in the title were published in England' in the mid-seventeenth century. ${ }^{24}$ In Bodies and Selves in Early Modern England, Michael Schoenfeldt explains, 'Galenic medicine provided [...] writers with a rich and malleable discourse able to articulate and explain the vagaries of human emotion in corporeal terms.' In a way, Galenic humours and passions made all sensation fluid as well as physical. Schoenfeldt reminds us that our post-Cartesian perspective makes it difficult to comprehend a time when selves were not separate from bodies. In seventeenth-century England, 'embodiments of emotion [are] not [...] enactments of dead metaphors but rather explorations of the corporeal nature of self ${ }^{25}$ When Herrick's narrator says he drowns in 
the vision of Julia's petticoat, Herrick probably does not use 'drown' as a simile. When he sees her petticoat, he does not feel like he is drowning. He is drowning. Schoenfeldt takes a compelling passage from Peter Brown's The Body and Society to illustrate just how embodied bodies were in the period:

Here were little fiery universes, through whose heart, brain, and veins there pulsed the same heat and vital spirit as glowed in the stars. To make love was to bring one's blood to the boil, as the fiery vital spirit swept through the beings, turning the blood into the whitened foam of semen. It was a process in which the body as a whole - the brain cavity, the marrow of the backbone, the kidneys, and the lower bowel region - was brought into play, 'as in a mighty choir'. The genital regions were mere points of passage. They were the outlets of a human Espresso machine. It was the body as a whole, and not merely the genitals, that made orgasm possible. ${ }^{26}$

Brown uses orgasm as a vivid example of early modern, specifically Galenic, bodily experience, and reminds us that sex and sensation are intimately connected. Indeed, the fourth book of De rerum natura is entitled 'Sensation and Sex'. Lucretius confirms Brown's description, in part, when he explains how the 'seed $[\ldots]$ travels through every member of the body, concentrating in certain reservoirs in the loins, and promptly awakens the generative organs' (Iv.1041-43; p. 122). These awoken genitals then seek out the source of desire ('whether [...] a lad with womanish limbs or a woman radiating love from her whole body') so that the lover can 'ejaculate the fluid drawn from out of his body into that body' (Iv.1054-55, 1057; p. 122). But, Lucretius explains, when it comes to desire, ejaculation is just one liquefying part of a sensual whole body experience:

Venus teases lovers with images. They cannot glut their eyes by gazing on the beloved form, however closely. Their hands can rub nothing from off those dainty limbs in their aimless roving over all the body. Then comes the moment when with limbs entwined they pluck the flower of youth. Their bodies thrill with the joy to come, and Venus is just about to sow the seed in the female fields. Body clings greedily to body; they mingle the saliva of their mouths and breathe hard down each other's mouths pressing them with their teeth. But all to no purpose. One can remove nothing from the other by rubbing, nor enter right in and be wholly absorbed, body in body; for sometimes it seems that that is what they are craving and striving to do, so hungrily do they cling together in Venus' fetters, while their limbs are unnerved and liquefied by the intensity of pleasure. At length, when the build-up of lust has burst out of their groin, there comes a slight intermission in the raging fever. But not for long. Soon the same frenzy returns. (Iv.1100-17; pp. 123-24)

This intensely erotic description suggests a few things. First, sex is not solely genital. Intercourse is one step in a process that involves seeing, touching, tasting and, one imagines, smelling and hearing too. Second, the bodily senses 
fail when it comes to desire. Elsewhere in De rerum natura Lucretius insists on the material nature of sensation. If 'from every object flows a stream of matter' (Iv.224-25; p. 110), then why can our hands 'rub nothing from off' our beloveds when we caress them (Iv.1102-03; p. 123)? Lucretius either contradicts himself in his description of sex, or he suggests that, when it comes to love, the 'flimsy tissues and filmy shapes' that float off our beloveds simply are not enough (Iv.158; p. 99). Like Herrick's narrator, we want to melt into one with our fulias, but we only are 'tease[d] [...] with images' that do not contain enough matter to satisfy. This leads to a third point, which has to do with insatiability. Even the genitals are essentially useless when it comes to the satisfaction of desire; intercourse and ejaculation may provide a 'slight intermission' from desire, but they have as little purpose as seeing, touching and tasting. Seeing Julia's undulating petticoat, hearing her melodious voice or smelling her perfumed breath are just as sexually satisfying as genital sex (that is, not satisfying at all).

Lucretius does imply that at least parts of our body liquefy when they are engaged in sexual intercourse. During sex, the 'limbs are unnerved and liquefied by the intensity of pleasure'. Here, the body's liquefaction is linked with its unnerving, which could mean the loss of sensation. But it could also mean that, during sex, the limbs are sensed so fully that their ability to sense is saturated. A handful of early modern writers argue that sexual desire does not just affect the abilities of the five senses; they say sexual desire is a sixth bodily sense, and because it holds power over the other senses it should be considered the true king of the senses. For instance, in The Anatomy of Melancholy (1621) Richard Burton mentions this sixth sense when he begins his discussion of the traditional five: 'Of Touching, Hearing, Seeing, Smelling, Tasting: to which you may adde Scaligers sixt sense of Titillation, if you please. ${ }^{, 27}$ Francis Bacon similarly cites Scaliger in Sylua syluarum (1627):

The Pleasure in the Act of Venus is the greatest of the Pleasures of the Senses: [...] Scaliger doth well, to make the Pleasure of Generation a Sixth Sense; And if there were any other differing Organs, and Qualified Perforations for the spirits to passe; there would be more than the Fiue Senses. ${ }^{28}$

Bacon claims sexual titillation is a sense because, like the other five senses, it has an organ and a portal that allows fluid spirits to exit (and enter) the body. To classify venery as a sense is to link it with knowledge ('carnal knowledge' takes on a new meaning here), as well as with pleasure. Venery might stupefy the other senses, but it does this by intensifying their pleasures.

In Exotericarvm Exercitationvm (1557) Julius Caesar Scaliger originally suggested that titillation was a sixth sense for a different reason. Daniel Jaeckle explains, 'in a section on touch and taste, Scaliger argues that the desire to copulate depends on a sixth sense that somehow includes touch and sight 
and results in titillation' ${ }^{29}$ Scaliger says that this 'sextus quidam sensus, sicut \& gustus: uterque non sine tactu: sed tamen aliud \& ab illo \& inter se'. The sixth sense is similar to taste and correlated with touch, yet it is different and something between these two senses. He continues, 'Gustus indiuiduo datus: alter ob speciem. Etenim si non allicerêntur illa voloptate: quotus quisque coire vellet?' Taste is granted for the individual, but the sixth sense is granted for the human species. The sixth sense is necessary, Scaliger argues, because if we were not satisfied with this 'illa uoloptate' (extreme pleasure) then we would rarely be willing to have sex. ${ }^{30}$ The sixth sense is a generative sense that is purposefully pleasurable because it is absolutely essential for the perpetuation of the species.

Scaliger states that, with the sixth sense, pleasure is a means to an end. But Bacon implies that sexual pleasure is the sixth sense; he calls it the 'Pleasure of Generation, ${ }^{31}$ We might say that sexual pleasure is to generation as taste is to sustenance. Taste helps us to discover foods and drinks that are necessary for survival, but, more often, we use the sense of taste for pleasure. The sixth sense works in the same way. Sex may be related to generation, but the sixth sense is focused on the pleasures (and pains) of sexual desire in general.

It is Bacon's sixth sense that finally helps to explain Herrick's liquefying depictions of the five traditional senses. In Hesperides, the desire for sexual pleasure defines the experience of sensation. Seeing, hearing, smelling, tasting and touching are all akin to sex. All are driven by the desire of individuals to (or not to) infuse with the people and objects they encounter. It is pleasurable to drink in a vision of Julia's undulating petticoat or to imagine inhaling her sweet scents. Even though Herrick's narrator cannot actually infuse with Julia (as Lucretius laments), poetic language can capture the truly desired terminus of love, which is the liquefaction and infusion of two sensual bodies.

Herrick's poetry is both about sensation and a demonstration of the experience of sensation, much like the spiced art installation that opened this chapter. The museum's curator suggests that we do not just view Neto's artwork, but we ingest it, are ingested by it, and become one with it. ${ }^{32}$ The same happens when we hear Herrick's verse. 'The Night-piece, to Julia' exemplifies this in its aim to enchant both its subject, Julia, and us, its readers. The first three stanzas paint a beautiful picture of Julia, walking at night, led by faeries, elves and other spirits. At line 16, Herrick states a transitional 'Then':

4. Then Fulia let me wooe thee,

Thus, thus to come unto me:

And when I shall meet

Thy silv'ry feet,

My soule Ile poure into thee.

(11. 16-20)

Once Julia has (and we have) been enchanted by poetry, then Herrick has access to woo her (and us). She (as we) will have been softened, or melted, by the 
lovely music that drew her to him. What the repeated 'Thus, thus' refers to is unclear; however, it could be read as a reference back to the first three lyric stanzas. He will woo her 'thus, thus', with poetry like that which we have just experienced. When Julia reaches Herrick in the fourth stanza, she becomes the poetry he writes; her 'silv'ry feet' are the poetic feet that comprise the lines of his verse. As a poem, or even simply as a woman wooed with poetry, Herrick can infuse his liquid soul with Julia, and with us, his readers.

Herrick's liquefying senses might make the most sense when we remember that the language of poetry is always the language of bodily sensation. In Poetry and the Fate of the Senses, Susan Stewart says the 'task of aesthetic production and reception in general is to make visible, tangible, and audible the figures of persons, whether such persons are expressing the particulars of sense impressions or the abstractions of reason' ${ }^{33}$ Poetry is an artistic expression of sensation that is '[e]rotic and rhetorical at once' $\cdot{ }^{34}$ Herrick reminds us that poetry physically touches us; we are supposed to feel something when we read it, hear it, touch it, sense it. And because his poems are themselves sensible objects, we might imagine that a little bit of Herrick infuses with us every time we open our senses to his verse. ${ }^{35}$

\section{Notes}

1 Ernesto Neto, Just like Drops in Time, Nothing. Textile and spices, 2002. Art Gallery of New South Wales (276.2002) www.artgallery.nsw.gov.au/collection/ works/276.2002/ [accessed 6 June 2013].

2 Anthony Bond, 'Sensing Space and the Place of Body', curator's essay for Art Gallery of New South Wales (1997) www.anthonybond.com.au/exhibitions/ ernesto-neto-agnsw-1997/ [accessed 6 June 2013] (para. 5 of 14).

3 All verse quotations are from The Complete Poetry of Robert Herrick, ed. by J. Max Patrick, rev. edn (New York: Norton, 1968); titles and line numbers are cited in the text.

4 Susan Stewart, 'Remembering the Senses', in Empire of the Senses: The Sensual Culture Reader, ed. by David Howes (Oxford: Berg, 2005), pp. 59-69 (p. 59).

5 Aristotle, De Anima (On the Soul), trans. by Hugh Lawson-Tancred (London: Penguin, 1986), III.8; p. 210. Hereafter cited in the text.

6 Michael Drayton, Idea XXIX, 'To the Senses', in Elizabethan Sonnet-Cycles, ed. by Martha Foote Crow (Chicago: McClurg, 1897), p. 38; 11. 5-11.

7 Louise Vinge, The Five Senses: Studies in a Literary Tradition (Lund: LiberLäromedel, 1975), p. 113.

8 Etymology of 'infuse, v.' from $O E D$.

9 Definition of 'conceit, n.' from $O E D$.

10 William Ian Miller, The Anatomy of Disgust (Cambridge, MA: Harvard University Press, 1997), p. xi.

11 Lillian Schanfield, “'Tickled with Desire': A View of Eroticism in Herrick's Poetry', Literature E Psychology, 39 (1993), 63-83 (p. 81). 
12 Schanfield, p. 63.

13 Thanks to Anita Butler (King's College London) for connecting my analysis of this poem to Heraclitus, who said 'you can't step into the same river twice'. In his assertion that the river absorbs part of his mistress, Herrick seems to disagree with the Heraclitean idea of perpetual change.

14 Vinge, p. 12.

15 Vinge, p. 15.

16 Elizabeth Harvey, 'Introduction: The "Sense of All Senses", in Sensible Flesh: On Touch in Early Modern Culture, ed. by Elizabeth Harvey (Philadelphia: Pennsylvania University Press, 2003), pp. 1-21 (p. 4).

17 Misty Anderson, 'Living in a Material World: Margaret Cavendish's The Convent of Pleasure', in Sensible Flesh, ed. by Harvey, pp. 187-204 (p. 189).

18 Lucretius, On the Nature of the Universe, trans. by R.E. Latham, rev. edn (London: Penguin, 1994), Iv.86-87; p. 97. Hereafter cited in the text.

19 John Godwin, 'Introduction,' in Lucretius, Nature of the Universe, trans. by Latham, p. xxxv.

20 A.E. Stallings, 'A Note on the Text and Translation', in Lucretius, The Nature of Things, trans. by A.E. Stallings (London: Penguin, 2007), p. xxviii.

21 John Evelyn, An essay on the first book of T. Lucretius Carus De rerum natura. Interpreted and made English verse by 7. Evelyn Esq (1656); John Dryden, The Annual miscellany, for the year 1694 being the fourth part of Miscellany poems: containing great variety of nem translations and original copies (1694).

22 For instance, the Poetry Foundation says, 'Like the serious Epicurean, Herrick seeks to maximize pleasure and minimize pain'. 'Biography: Robert Herrick, 1591-1674', Poetry Foundation (2013) www.poetryfoundation.org/bio/robert-herrick [accessed 10 June 2013].

23 Bruce Smith, The Key of Green: Passion and Perception in Renaissance Culture (Chicago: University of Chicago Press, 2009), pp. 29-30.

24 Smith, p. 30.

25 Michael Schoenfeldt, Bodies and Selves in Early Modern England (Cambridge: Cambridge University Press, 1999), pp. 6, 11, 8.

26 Peter Brown, The Body and Society: Men, Women, and Sexual Renunciation in Early Christianity (New York: Columbia University Press, 1988), p. 17.

27 Richard Burton, The Anatomy of Melancholy (Oxford, 1621), C[1]r: Part 1, Section 1, Member 2, Subsection 6.

28 Francis Bacon, Sylua Syluarum, or A Naturall Historie (1627), p. 173.

29 Daniel Jaeckle, 'The Sixth Sense in Cleveland's "The Hecatomb to his Mistresse", Notes and Queries, 54 (2007), 411-12 (p. 412).

30 Julius Caesar Scaliger, Exotericarvm Exercitationvm (Paris, 1557), Exercitatio cclxxxvi.3. Thanks to Eric Kraemer (University of Wisconsin, La Crosse) and Annie Wattez for their translation assistance.

31 Bacon, p. 173.

32 Bond, para. 5 of 14.

33 Susan Stewart, Poetry and the Fate of the Senses (Chicago: University of Chicago Press, 2002), p. 2.

34 Stewart, p. 26. 
35 Thanks to Rick Rambuss (Brown University) for his mentorship when I began working on Herrick at Emory University. Thanks also to the University of Wisconsin, La Crosse, for grants that enabled me to conduct research at the Folger Shakespeare Library, to draft this essay, and to travel to the London Renaissance Seminar (Shakespeare's Globe and Birkbeck, University of London) where I met the kind people who believed it had a place in this collection. 